\title{
New record of three economic Hypnea species (Gigartinales) in Korea
}

\author{
Pil Joon Kang and Ki Wan Nam ${ }^{*}$ (1)
}

\begin{abstract}
Three economic marine algae that have been used as food and carrageenan sources were collected from Korea during a survey of marine algal flora. They share the generic features of Hypnea, and three major clades supported by the sectional features were confirmed in a phylogenetic tree based on rbcL sequences. The first species, which belongs to a species group corresponding to the sect. Spinuligerae, nests in the same clade with Hypnea yamadae in a genetic distance of $0 \%$. It is morphologically characterized by an entangled base, subcompressed or subterete to terete axes, somewhat percurrent main axis, irregularly alternately branching with wide angle, and rarely hooked spinous branchlets. The second one is also referred to the sect. Spinuligerae and formed the same clade as Hypnea cenomyce. The genetic distance between both sequences was calculated as $0.0-0.1 \%$, which is considered to be intraspecific. This species is distinct by somewhat entangled thallus at the basal part, percurrent axis, short spine-like branchlets densely covering the axis, and medullary lenticular thickenings. The third alga, which forms a species group corresponding to the sect. Pulvinatae, nests in the same clade as Hypnea nidulans (no intraspecific divergence). It shows occasionally epiphytic habitat rather than epilithic habitat of low mat-forming growth and percurrent erect main axes with dense lateral branchlets. Based on these morphological and molecular data, the three Korean species are identified as H. yamadae, H. cenomyce, and H. nidulans. This is the first record of the Hypnea species in Korea.
\end{abstract}

Keywords: Hypnea species, Economic marine algae, rbcL, Molecular data, First record, Korea

\section{Background}

The marine red algal genus Hypnea J.V. Lamouroux, which has a wide geographical distribution around the world, is economically important as food and as one of the sources of carrageenan, particularly in the tropics (Mshigeni and Chapman 1994; Geraldino et al. 2010). This genus was established based on six species (Lamouroux 1813) but later lectotypified by $H$. musciformis (Wulfen) J.V. Lamouroux (Kylin 1930; Papenfuss 1958).

Agardh (1852) proposed three sections within the genus Hypnea on the basis of thallus habit. The sect. Pulvinatae has creeping thalli of intricate cushion-like mat form. The sect. Virgatae is characterized by an erect, caespitose, and non-intricate thallus with main axis and dense lateral branchlets, while the sect. Spinuligerae in which the species show intricate and caespitose thalli with alternate branching and short spine-like branchlets. Recently, this infrageneric taxonomic scheme, with some exceptional

\footnotetext{
* Correspondence: kwnam@pknu.ac.kr

Department of Marine Biology, Pukyong National University, Busan 48513, Korea
}

species, was strongly supported by molecular analyses (Geraldino et al. 2010).

Since Lamouroux (1813), many species have been reported in this genus (Agardh 1851, 1852; Tanaka 1941, 1960; Schneider and Searles 1976; Nauer et al. 2014, 2015; Geraldino et al. 2009, 2010; Jesus et al. 2013). Therefore, Hypnea is a large genus in which 60 species are currently accepted within the family Cystocloniaceae (Guiry and Guiry 2018). This genus is characterized by a terete to compressed, branched thalli with short lateral branchlets, protuberant globular cystocarps, and zonately divided tetrasporangia on short lateral branchlet (Lamouroux 1813; Mshigeni 1978; Womersley 1994). However, species delimitation is complicated by the high degree of morphological variation within individual species, which may be chiefly influenced by environmental factors occurring in specific habitats. Furthermore, the taxonomy based mainly on vegetative features, with a relatively simple and plastic morphology, has caused many difficulties in identifying the species within Hypnea (Nauer et al. 2014, 2016; the present study). 
In Korea, 13 species have been reported. During a survey of marine algal flora, three gigartinalean species were collected from Korea. They share the generic morphological features of Hypnea. The Hypnea species are newly recorded in Korea based on the morphological and molecular analyses herein.

\section{Methods}

Specimens for this study were collected from Pohang and Sacheonjin located on the eastern coasts of Korea. Taxonomic data were obtained from fresh, liquid-preserved, and herbarium specimens. Liquid-preserved material was stored in a $10 \%$ solution of formalin/seawater. Blades dissected from the cleared materials were hand sectioned, transferred to a slide with distilled water, and mounted in pure glycerin. Measurements are given as width and length. For permanent slides, the glycerin was exchanged with $10-20 \%$ corn syrup.

Total genomic DNA was extracted from silica gel-preserved samples using the DNeasy Plant Mini Kit (Qiagen, Hilden, Germany) according to the manufacturer's protocol. Before extraction, dried material was crushed with liquid nitrogen using a mortar and pestle. Extracted DNA was used for amplification of ribulose-1, 5-bisphosphate carboxylase large subunit $(r b c \mathrm{~L})$ regions. For $r b c \mathrm{~L}$, the gene was amplified in three overlapping parts with the primer pairs FrbcL start (5'-TGTGTTGTCGACATGTCTA ACTCTGTAGAAG-3') - R753 (5'-GCTCTTTCATACATA TCTTCC-3'), F492 (5'-CGTATGGATAAATTTGGTC G-3') - R1150 (5'-GCATTTGTCCGCAGTGAATACC-3'), and F993 (5'-GGTACTGTTGTAGGTAAATTAGAAG G-3') - RrbcS (5'-TGTGTTGCGGCCGCCCTTGTGTT AGTCTCAC-3') (Freshwater and Rueness 1994). PCR amplifications were performed in a TaKaRa PCR Thermal Cycler Dice (TaKaRa Bio Inc., Otsu, Japan). PCR was performed with an initial denaturation step at $94{ }^{\circ} \mathrm{C}$ for $10 \mathrm{~min}$, followed by 35 cycles of $30 \mathrm{~s}$ at $90^{\circ} \mathrm{C}, 30 \mathrm{~s}$ at $50^{\circ}$ $\mathrm{C}$, and $2 \mathrm{~min}$ at $72{ }^{\circ} \mathrm{C}$, with a final 10 -min extension cycle at $72{ }^{\circ} \mathrm{C}$. The PCR products were moved to Macrogen Sequencing Service for sequencing (Macrogen, Seoul, Korea). The PCR primers were also used for sequencing.

Six $r b c \mathrm{~L}$ sequences were generated. A total of 31 sequences from Hypnea, including Cystoclonium purpureum (Hudson) Batters as an outgroup, was aligned using 1356 base pairs (bp) of the $r b c L$ gene using BioEdit (Hall 1999). Phylogenetic analyses were performed using neighbor-joining and maximum-likelihood methods using Mega 6 program. Bootstrap values were calculated with 1000 replications. $R b c \mathrm{~L}$ sequences of other species were obtained from GenBank.

\section{Results}

Hypnea yamadae Tanaka 1960: 94

Type locality: Uji Islands, Kagoshima Prefecture, Japan (Yamagishi and Masuda 1997)
Korean name: Mit-eong-kin-ga-si-u-mu nom. nov. (신 칭 : 밑엉킨가시우무)

Specimens examined: NIBRAL0000146496, MGARBb0 00744, MGARBb000745, MGARBb000746 (Daebori: 07. viii.2014)

Habitat: Epilithic in upper to lower intertidal

Morphology: Thalli up to $10-15 \mathrm{~cm}$ high, epilithic, subcompressed or subterete to terete, somewhat entangled at base, without iridescence, light brown to dark brown in color, cartilaginous in texture (Fig. 1a); main axes more or less percurrent, issuing irregularly or alternately branches with wide angle and proliferations; branches bearing a few branchlets in alternate to spiral manner (Fig. 1b); branchlets short, spinous, slender, rarely hooked, without constriction near base, 5-20 mm long (Fig. 1d); apical cells distinct at the apices of axes (Fig. 1c); lenticular thickenings usually absent in the wall of medullary cells; cortex 2-3 cell layers thick; medullary cells round to elliptical in transverse section, linear to cylindrical shape in longitudinal section, with many pit connection between adjacent cells; tetrasporangia produced from cortical cell (Fig. 1f), restricted in ultimate branchlets (Fig. 1e), zonately divided, 25-35 × 55-70 $\mu \mathrm{m}$. Sexual plants were not collected during the present study.

\section{Hypnea cenomyce J. Agardh 1851: 452}

Type locality: ad oras Novae Hollandiae (Silva et al. 1996)

Korean name: God-eun-ga-si-u-mu nom. nov. (신칭 : 곧은가시우무)

Specimens examined: NIBRAL0000146479, MGARBb 000747, MGARBb000748, MGARBb000749 (Sacheonjin: 03.vii.2014)

Habitat: Epilithic in upper to lower intertidal

Morphology: Thalli up to $10-15 \mathrm{~cm}$ high, epilithic, terete, somewhat entangled at basal part, without iridescence, dark red to brown in color, cartilaginous in texture (Fig. 2a); main axes often more or less percurrent, issuing irregular or alternate branches and proliferations; branches bearing abundant branchlets in alternate to spiral manner (Fig. 2b); branchlets short, spinous, usually with constriction near base, 5-15 $\mathrm{mm}$ long; apical cells distinct at the apices of axes (Fig. 2d); lenticular thickenings occasionally present in the medullary cell walls (Fig. 2c); cortex 2-3 cell layers thick; medullary cells round to elliptical in transverse section, linear to cylindrical shape in longitudinal section, with many pit connection between adjacent cells; tetrasporangia produced from cortical cell (Fig. 2f), restricted in ultimate branchlets (Fig. 2e), zonately divided, 10-20 $\times$ $20-40 \mu \mathrm{m}$. Sexual plants were not collected during the present study.

Hypnea nidulans Setchell 1924: 161 
a

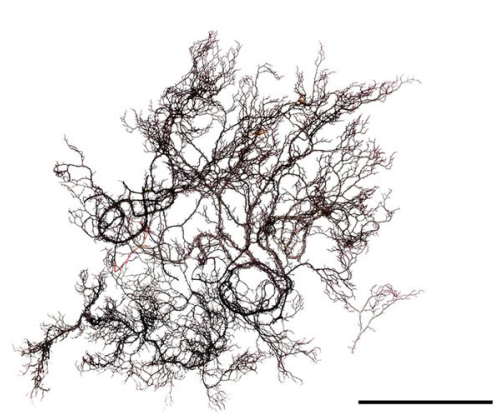

C

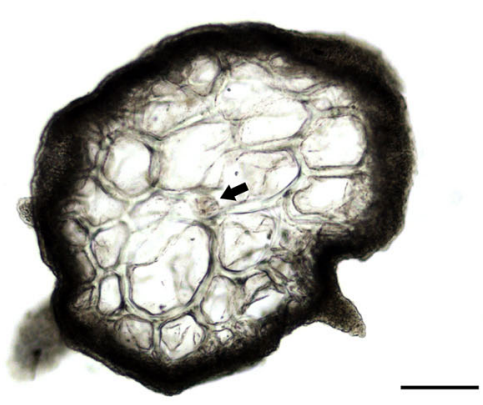

e

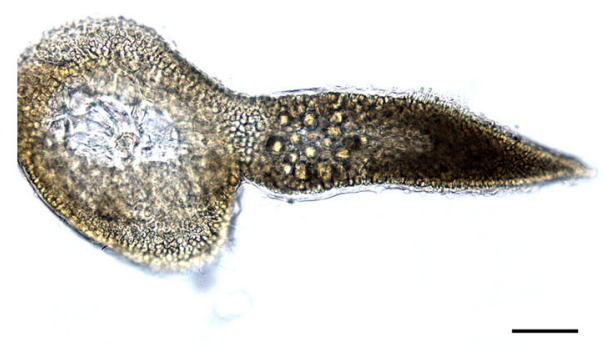

b

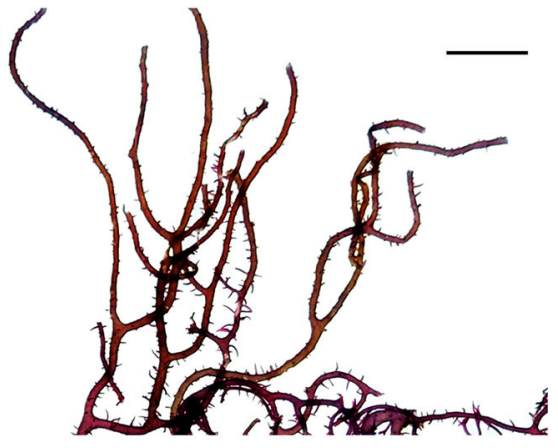

d

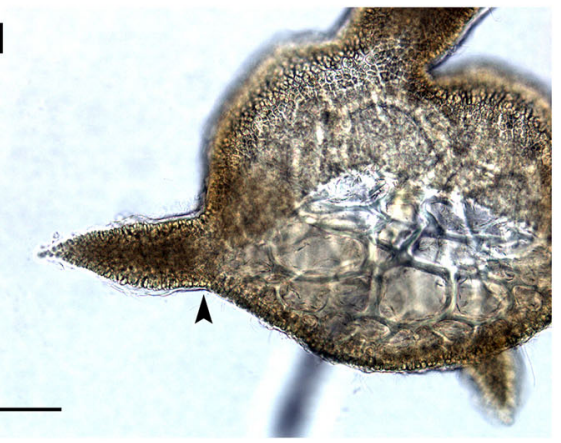

f

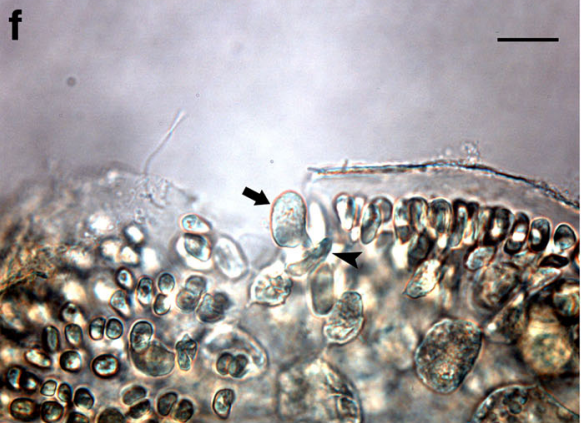

Fig. 1 Hypnea yamadae Tanaka. a Herbarium specimen entangled at the base. b Details of vegetative branches. c Subterete to subcompressed branch with the axial cell (arrow) in the transverse section. $\mathbf{d}$ Spinous branchlet without basal constriction (arrow). e Ultimate branchlet with tetrasporangia. f Tetrasporangial initial (arrow) produced from the cortical cell (arrowhead). Bars in a $3 \mathrm{~cm}, \mathbf{b ~} 5 \mathrm{~mm}, \mathbf{c} 150 \mu \mathrm{m}$, d $80 \mu \mathrm{m}$, e $80 \mu \mathrm{m}$, f $20 \mu \mathrm{m}$

Type locality: Tutuila Island, American Samoa (Silva et al. 1996; Setchell 1924)

Korean name: Gi-neun-ga-si-u-mu nom. nov. (신칭 : 기는가시우무)

Specimens examined: NIBRAL0000146497, MGARBb0 00741, MGARBb000742, MGARBb000743 (Sachenjin: 20.vii.2017)

Habitat: Epilithic or occasionally epiphytic in upper to lower intertidal

Morphology: Thalli up to $5-10 \mathrm{~cm}$ high, interwoven, loosely entangled, terete to subterete, without iridescence, red to brown in color, cartilaginous in texture (Fig. 3a); main axes erect, often percurrent, issuing irregularly branches and proliferations; branches bearing numerous branchlets in alternate to spiral manner (Fig. 3b); branchlets short, linear to lanceolate, usually with constriction near base, $2-10 \mathrm{~mm}$ long; apical cells distinct at the apices of axes; lenticular thickenings present in the wall of medullary cells (Fig. 3c, d); cortex 2-3 cell layers thick; medullary cells round to elliptical in transverse section, linear to cylindrical shape in longitudinal section, with many pit connection between adjacent cells; tetrasporangia produced from cortical cell (Fig. 3f), restricted in ultimate branchlets (Fig. 3e), zonately divided, $20-30 \times 45-60 \mu \mathrm{m}$. Sexual plants were not collected during the present study.

\section{Discussion}

In a phylogenetic tree based on $r b c \mathrm{~L}$ sequences, three major clades were confirmed (Fig. 4). These clades appear to be supported by the sectional features suggested by Agardh (1852). 
a

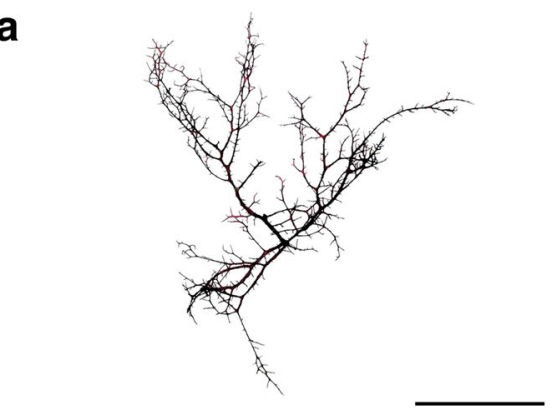

b
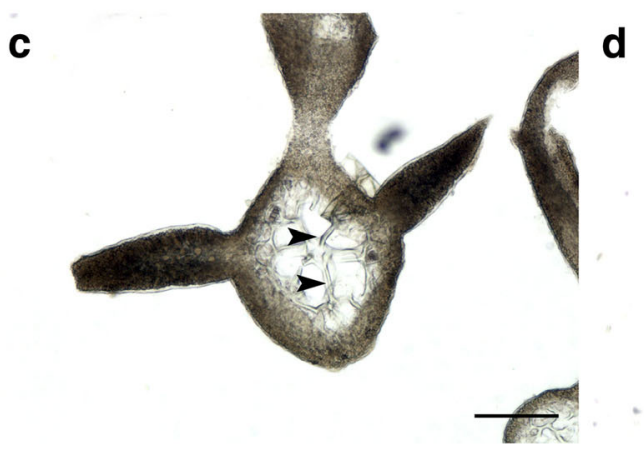

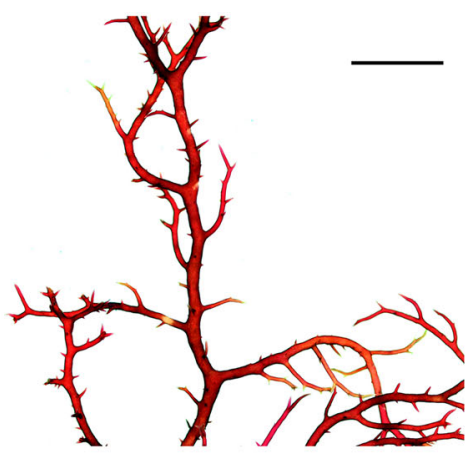

d
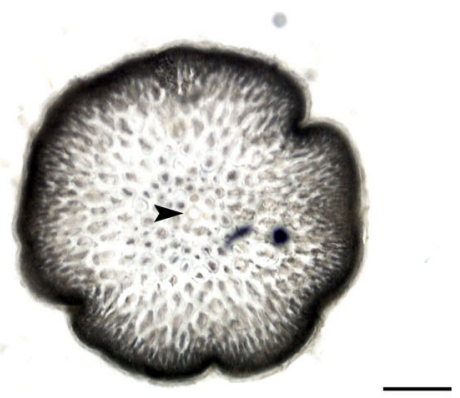
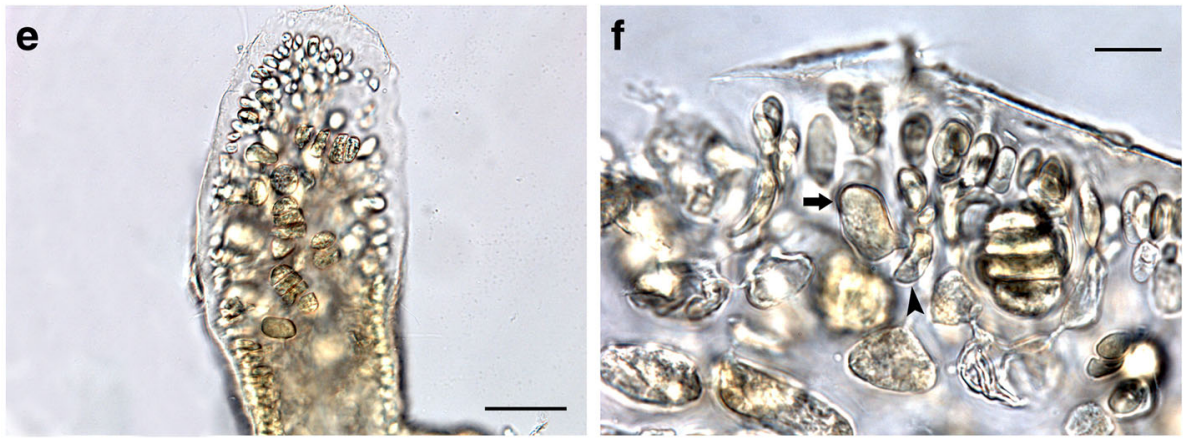

Fig. 2 Hypnea cenomyce J. Agardh. a Herbarium specimen. b Details of the tetrasporangial branches. c Lenticular thickenings (arrowheads) in the medullary cell walls. $\mathbf{d}$ Transverse section of the branch with axial cell (arrowhead). e Tetrasporangial branchlet. $\mathbf{f}$ Tetrasporangial initial (arrow) produced from the cortical cell (arrowhead). Bars in a $3 \mathrm{~cm}$, b $5 \mathrm{~mm}, \mathbf{c} 200 \mu \mathrm{m}, \mathbf{d} 200 \mu \mathrm{m}$, e $50 \mu \mathrm{m}$, and f $15 \mu \mathrm{m}$

The first species, which belongs to a species group corresponding to the sect. Spinuligerae, nests in the same clade with $H$. yamadae in a genetic distance of $0 \%$ (Fig. 4). It is also morphologically characterized by an entangled base of creeping branches, subcompressed or subterete to terete axes, somewhat percurrent main axis, irregular or alternate branching with wide angle, and rarely hooked spinous branchlets as $H$. yamadae reported previously by some authors (Tanaka 1960; Yamagishi and Masuda 1997). However, somewhat terete thalli and slender branchlets rarely hooked in the species differed from the original description of $H$. yamadae (Tanaka 1960) (Table 1). It was distinguished from its sister species, $H$. rosea Papenfuss (1947), by terete branch rather than subcompressed or subterete to terete one.
The second one is also referred to the sect. Spinuligerae and formed the same clade as $H$. cenomyce (Fig. 4). The genetic distance between both sequences within the clade was calculated as $0.0-0.1 \%$. In general, the presence or absence of medullary lenticular thickenings is considered as one of the useful taxonomic characters in Hypnea (Tseng 1984; Chiang 1997; Xia and Wang 1997; Geraldino et al. 2010). It has thickenings in medullary cell walls like Hypnea cenomyce (Chiang 1997; Yoshida 1998) (Table 1) and is distinguished from other Korean Hypnea species, such as $H$. boergesenii, $H$. cornuta, $H$. flexicaulis, $H$. japon$i c a, H$. saidana, and $H$. spinella, by the presence of this feature. H. flava forming its sister clade is distinguished from $H$. cenomyce by epiphytic habitat and presence of anastomoses (Nauer et al. 2016, see table 2). In addition to the presence of lenticular thickenings in the medullary cell 


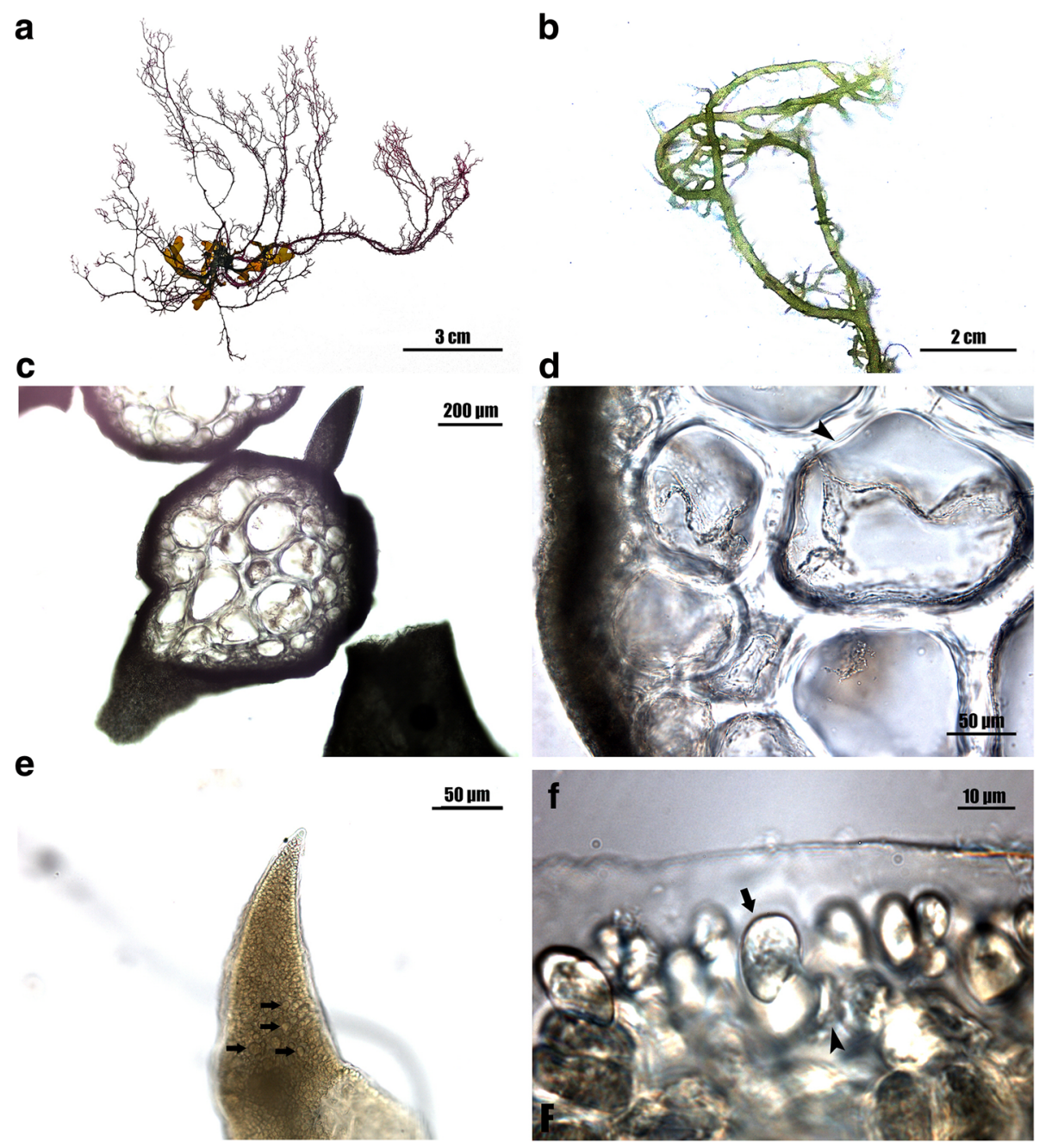

Fig. 3 Hypnea nidulans Setchell. a Herbarium specimen. b Details of vegetative branches. c Transverse section of the branch. $\mathbf{d}$ Lenticular thickening (arrowhead). e Branchlet with tetrasporangia (arrows). f Tetraspornagia initial (arrow) produced from the cortical cell (arrowhead). Bars in a $3 \mathrm{~cm}$, b $2 \mathrm{~cm}, \mathbf{c} 200 \mu \mathrm{m}, \mathbf{d} 50 \mu \mathrm{m}, \mathbf{e} 50 \mu \mathrm{m}$, and f $10 \mu \mathrm{m}$

walls, this Korean alga is characterized by somewhat entangled thallus at the basal part, percurrent axis, and short spine-like branchlets densely covering axis.

The third alga, which forms a species group corresponding to the sect. Pulvinatae, nests in the same clade as $H$. nidulans (no intraspecific divergence) (Fig. 4). According to Tanaka (1941), H. nidulans is loosely entangled, and tetrasporangial sori are saddle-shaped, while $H$. pannosa has densely entangled plants and tetrasporangial sori usually growing on one side of the branchlets, then gradually completely surrounding the branchlets. Dawson (1954) distinguished $H$. pannosa from $H$. nidulans by the small size and compact tufts of the former species, but he reduced $H$. nidulans to the synonymy of $H$. pannosa based on an examination of the type specimens of both species (Dawson 1961). Later, however, Silva et al. (1996) retained it as a separate species. This is currently accepted (Guiry and Guiry 2018) and is also supported by the present study. $H$. nidulans appears to be distinguished from those species forming a sister group, such as $H$. japonica, $H$. caespitosa, $H$. pannosa, and $H$. viridis, by occasionally epiphytic habitat rather than epilithic habitat of low matforming growth, as based on the present observation. Percurrent erect main axes, with dense lateral branchlets, also distinguish $H$. nidulans from those species. This is a feature of the sect. Virgatae rather than the sect. Pulvinatae.

\section{Conclusions}

In general, the value of interspecific divergence in the Gigartinales varies from 2.8 to $16.5 \%$ (Hommersand et al. 1994; Kato et al. 2009). The interspecific divergence range within the genus Hypnea was calculated as $0.6-7.6 \%$ in 


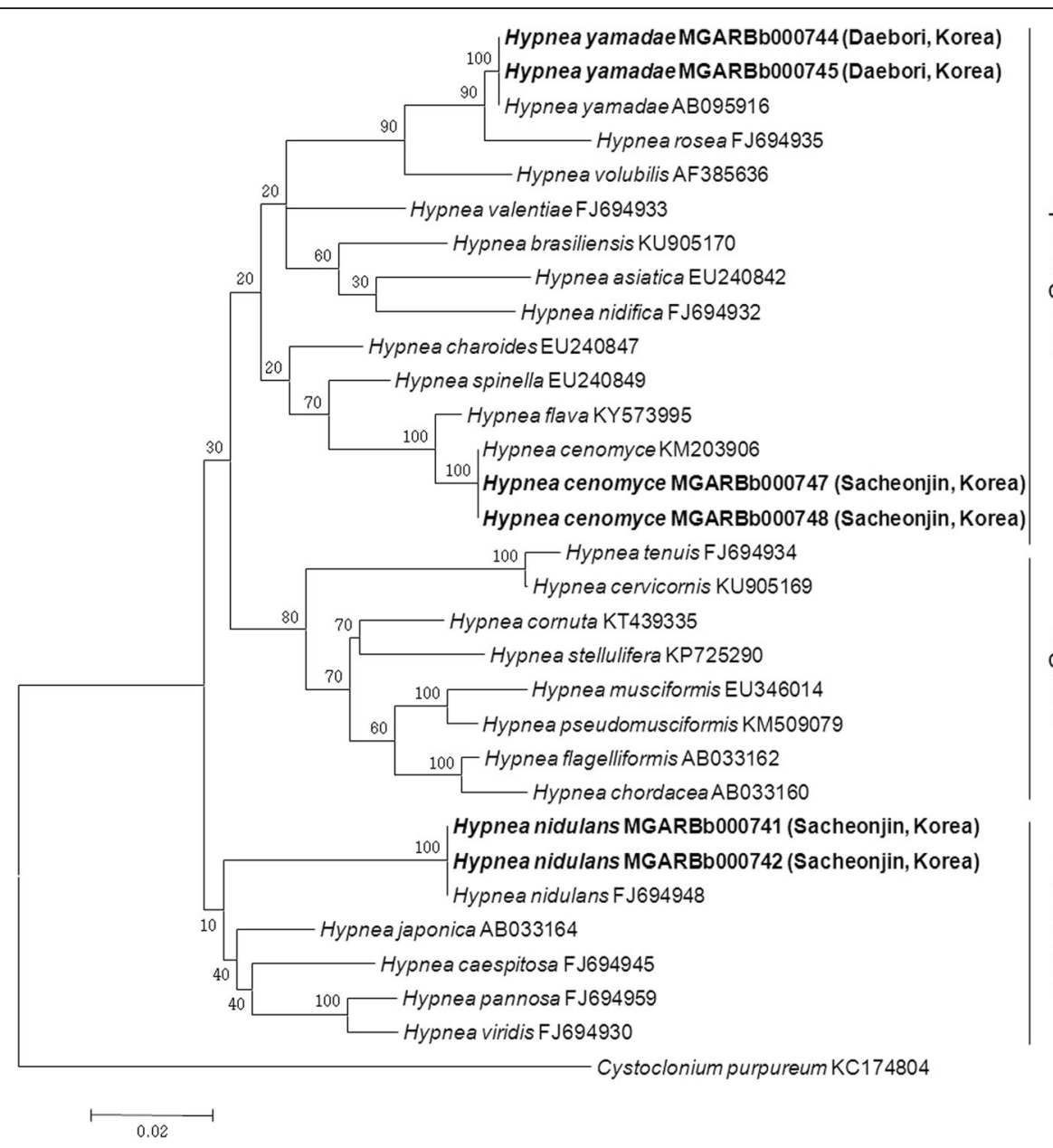

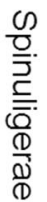

Fig. 4 Phylogenetic tree of Hypnea species obtained from maximum-likelihood analysis based on rbcL sequences. Bootstrap percentages (1000 replicates samples) are shown above the branches. Scale bar $=0.02$ substitutions/site

Table 1 Comparison of morphological features found in the three Hypnea species

\begin{tabular}{|c|c|c|c|}
\hline \multirow[t]{2}{*}{ Characters } & \multicolumn{3}{|l|}{ Species } \\
\hline & H. yamadae & H. cenomyce & H. nidulans \\
\hline Habitat & Epilithic in intertidal to subtidal & Epilithic in intertidal & $\begin{array}{l}\text { Epilithic or occasionally } \\
\text { epiphytic in intertidal }\end{array}$ \\
\hline Thalli & Terete to compressed & Terete & Terete to subterete \\
\hline Size (cm) & $9-37$ & $4-15$ & $2-10$ \\
\hline Branching type & Irregular, alternate or dichotomous & Alternate or irregular & Alternate to spiral, irregular \\
\hline Branchlets & A few & Several (or abundant) & Numerous \\
\hline Basal constriction of branchlets & Absent & Present & Present \\
\hline Hooked branchlets & Absent or rarely present & Absent & Absent \\
\hline Lenticular thickening & Absent & Often or occasionally present & Present \\
\hline Size of tetrasporangia ( $\mu \mathrm{m})$ & - & $50 \times 25$ & $12 \times 58$ \\
\hline References & $\begin{array}{l}\text { Tanaka 1960; Yamagishi and } \\
\text { Masuda 1997; the present study }\end{array}$ & Chiang 1997; the present study & $\begin{array}{l}\text { Chiang 1997; Yamagishi and } \\
\text { Masuda 1997; the present study }\end{array}$ \\
\hline
\end{tabular}


the present study. This indicates that the genetic distance of $0.0-0.1 \%$ between both sequences within each clade formed by the three Korean species is intraspecific within the genus. Based on these morphological and molecular analyses, these Korean Hypnea species are identified as $H$. yamadae, $H$. cenomyce, and $H$. nidulans. This is the first record of these Hypnea species in Korea.

\section{Abbreviation \\ rbcL: Ribulose-1, 5-bisphosphate carboxylase large subunit}

\section{Funding}

This work was supported by a grant from the National Institute of Biological Resources (NIBR) funded by the Ministry of Environment (MOE) of the Republic of Korea (NIBR201701204) and by the Marine Biotechnology Program of the Korea Institute of Marine Science and Technology Promotion (KIMST) funded by the Ministry of Oceans and Fisheries (MOF) (No. 20170431).

\section{Availability of data and materials}

All datasets analyzed during the current study are available from the corresponding author on reasonable request.

\section{Authors' contributions}

PJK conducted the research, analyzed the materials, and prepared the draft manuscript. KWN designed and directed the study and finalized the manuscript. Both authors read and approved the final manuscript.

\section{Ethics approval and consent to participate}

Not applicable.

\section{Consent for publication}

Not applicable.

\section{Competing interests}

The authors declare that they have no competing interests.

\section{Publisher's Note}

Springer Nature remains neutral with regard to jurisdictional claims in published maps and institutional affiliations.

\section{Received: 11 June 2018 Accepted: 5 August 2018}

\section{Published online: 02 November 2018}

\section{References}

Agardh JG. Species genera et ordines algarum, seu descriptiones succinctae specierum, generum et ordinum, quibus algarum regnum constituitur. Volumen secundum: algas florideas complectens. Part 2, fasc. 1. Lund: C.W.K. Gleerup; 1851.

Agardh JG. Species Genera et Ordines Algarum, vol. 2. Lund: G. W. Gleerup; 1852.

Chiang Y-M. Species of Hypnea Lamouroux (Gigartinales, Rhodophyta) from Taiwan. In: Abbott IA, editor. Taxonomy of economic seaweeds, vol. 6. La Jolla, California: California Sea Grant College System; 1997. p. 163-77.

Dawson EY. Marine plants in the vicinity of the Institut Oceanographique de Nha Trang. Viet Nam Pac Sci. 1954;8:373-481.

Dawson EY. Marine red algae of Pacific Mexico. Part 4, Gigartinales. Pac Nat. 1961; 2:191-343.

Freshwater DW, Rueness J. Phylogenetic relationships of some European Gelidium (Gelidiales, Rhodophyta) species based upon rbcL nucleotide sequence analysis. Phycologia. 1994;33:187-94.

Geraldino PJL, Riosmena-Rodriguez R, Liao LM, Boo SM. Phylogenetic relationships within the genus Hypnea (Gigartinales, Rhodophyta), with a description of H. caespitosa sp. nov. J Phycol. 2010;46:336-45.

Geraldino PJL, Yang EC, Kim MS, Boo SM. Systematics of Hypnea asiatica sp. nov. (Hypneaceae, Rhodophyta) based on morphology and nrDNA SSU, plastid rbcL, and mitochondrial cox1. Taxon. 2009;58:606-16.

Guiry MD, Guiry GM. AlgaeBase. World-wide electronic publication, National University of Ireland, Galway http://www.algaebase.org. Accessed 15 May 2018.

Hall TA. BioEdit: a user-friendly biological sequence alignment editor and analysis program for Windows 95/98/NT. Nucleic Acids Symp Ser. 1999;41:95-8.
Hommersand MH, Fredericq S, Freshwater DW. Phylogenetic systematics and biogeography of the Gigartinaceae (Gigartinales, Rhodophyta) based on sequence analysis of rbcL. Bot. 1994;37:193-203.

Jesus PB, Guimarães SMPB, Nunes JMC. Hypnea platyclada a new species of red alga (Rhodophyta, Cystocloniaceae) from Brazil. Phytotaxa. 2013;85:26-34.

Kato A, Guimarães SMPB, Kawai H, Masuda M. Characterization of the crustose red alga Peyssonnelia japonica (Rhodophyta, Gigartinales) and its taxonomic relationship with Peyssonnelia boudouresquei based on morphological and molecular data. Phycol Res. 2009:57:74-86.

Kylin H. U“' ber die Entwicklungsgeschichte der Florideen. Acta Univ Lund. 1930 26:1-104.

Lamouroux JVF. Essai sur les genres de la famille des thalassiophytes non articulées. Ann Mus Hist Nat, Paris. 1813:20:21-47. 115-139, 267-293

Mshigeni KE. The biology and ecology of benthic marine algae with special reference to Hypnea (Rhodophyta, Gigartinales): a review of the literature. Biblioth Phycol. 1978;37:1-168.

Mshigeni KE, Chapman DJ. Hypnea (Gigartinales, Rhodophyta). In: Akatsuka I, editor. Biology of economic algae. The Hague: SPB Academic Publishing; 1994. p. 245-81.

Nauer F, Cassano V, Oliveira MC. Description of Hypnea pseudomusciformis sp. nov., a new species based on molecular and morphological analyses, in the context of the H. musciformis complex (Gigartinales, Rhodophyta). J Appl Phycol. 2015;27:2405-17.

Nauer F, Guimarăes NR, Cassano V, Yokoya NS, Oliveira MC. Hypnea species (Gigartinales, Rhodophyta) from the southeastern coast of Brazil based on molecular studies complemented with morphological analyses, including descriptions of Hypnea edeniana sp. nov. and H. flava sp. nov. Eur J Phycol. 2014:49:550-75.

Nauer F, Cassano V, Oliveira MC. Hypnea wynnei and Hypnea yokoyana (Cystocloniaceae, Rhodophyta), two new species revealed by a DNA barcoding survey on the Brazilian coast. Phytotaxa. 2016;268:123-34.

Papenfuss GF. New marine algae from South Africa: I. Univ Calif Publ Bot. 1947; 23:1-15.

Papenfuss GF. Notes on algal nomenclature. IV. Various genera and species of Chlorophyceae, Phaeophyceae and Rhodophyceae. Taxon. 1958;7:104-9.

Schneider CW, Searles RB. North Carolina marine algae. VII. New species of Hypnea and Petroglossum (Rhodophyta, Gigartinales) and additional records of other Rhodophyta. Phycologia. 1976;15:51-60.

Setchell WA. American Samoa: part I. Vegetation of Tutuila Island part II. Ethnobotany of the Samoans part III. Vegetation of Rose Atoll. Publications of the Carnegie Institution of Washington. 1924;341:1-275.

Silva PC, Basson PW, Moe RL. Catalogue of the benthic marine algae of the Indian Ocean. Univ Calif Publ Bot. 1996;79:1-1259.

Tanaka T. The genus Hypnea from Japan. Sci Papers Inst Algol Res Fac Sci Hokkaido Univ. 1941;2:227-50.

Tanaka T. Studies on some marine algae from southern Japan III. Mem Fac Fish Kagoshima Univ. 1960;9:91-105.

Tseng CK. Common seaweeds of China. Beijing: Science Press; 1984.

Womersley HBS. The marine benthic flora of southern Australia, part IIIA, Bangiophyceae and Florideophyceae (Acrochaetiales, Nemaliales, Gelidiales, Hildenbrandiales and Gigartinales sensu lato). Australian Biological Resources Study: Canberra; 1994.

Xia BM, Wang YQ. Some species of the genus Hypnea (Gigartinales, Rhodophyta) from China. In: Abbott IA, editor. Taxonomy of economic seaweeds, vol. 6. La Jolla, California: California Sea Grant College System; 1997. p. 193-206.

Yamagishi Y, Masuda M. Species of Hypnea from Japan. In: Abbott IA, editor. Taxonomy of economic seaweeds Vol. 6. La Jolla, California: California Sea Grant College System; 1997. p. 135-62.

Yoshida T. Marine algae of Japan. Tokyo: Uchida Rokakuho Publishing: 1998. 